\title{
Blue Ocean Shift to Adjust the Pendulum in IB Publications: \\ Why Our Field Needs to Nurture a New Breed of Journals
}

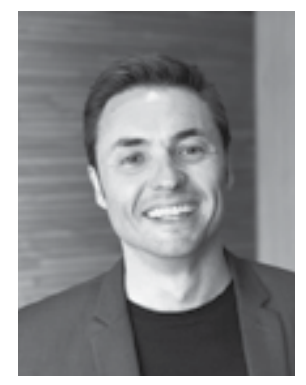

Daniel Rottig, Ph.D., Outgoing Editor

\author{
Daniel Rottig, Florida Gulf Coast University, USA
}

With the previous issue of AIB Insights, I have concluded my term as Editor, and a new editorial team has now taken charge for the next 3-year term. I have been asked by the leadership of the Academy of International Business to write an extended farewell editorial reflecting on my 6 years of editorial service for AIB Insights (3 years as Editor from 2016-18 and 3 years as Associate Editor from 2013-15). In a nutshell, it has been a great ride!

\section{The Raison d'être for AlB Insight's}

\section{Blue Ocean Shift}

When applying for an editorial position back in 2012, I submitted a 3-page application letter to the AIB Executive Board which delineated my vision for $A I B$ Insights and sketched out my ideas for how to achieve this vision. In this letter, referring to the now widely used concept of a "blue ocean strategy" (Kim \& Mauborgne, 2015), I stated that "AIB Insights has, in my opinion, carved out a "blue ocean" in that it fulfills a specific and unique purpose in the international business field that is currently not being accomplished by other journals: it publishes contemporary issues, novel ideas and new frontiers in international business education, research and practice in the form of short articles written in an interesting, less theoretical and academic, and more informative and provocative writing style that makes it accessible to a broader, cross-disciplinary audience." I proposed to build on and further substantiate this unique positioning of $A I B$ Insights through new ideas and initiatives and, using the words of the authors who coined the term in the subtitle of their latest book titled Blue Ocean Shift (Kim \& Mauborgne, 2017), I aimed to "inspire confidence and seize new growth" for the journal and thus, for the "blue ocean" it has created.

When being elected to serve in an editorial role for the journal at the 2012 annual conference of the Academy of International Business, as the journal's first-ever Associate Editor for a 3-year term with the possibility to serve for a second 3-year term as Editor, I was therefore very excited and humbled by the confidence and trust the AIB had bestowed in me to implement my vision. It is astonishing to realize how fast time has passed by over the past six years during which I have had the honor to serve for AIB Insights, a period of time that constitutes one third of the existence of the journal, which published its first issue in 2001. Over my tenure in an editorial role, I believe, AIB Insights has not only become an even more impactful and well-respected conduit for interesting, topical, current and thought-provoking articles, but also has been instrumental in defining and further developing a new space (or blue ocean) in the field of international business that complements traditional academic journals. The timely, concise and fresh nature of the articles published in AIB Insights, which are increasingly interactive and predominantly published in coherent and focused issues, communicate novel ideas and rigorous academic research in an unconventional and non-traditional way. In so doing, AIB Insights has made the work of IB scholars readily accessible to a broader audience of practitioners, educators and policymakers as well as colleagues in other fields, in addition to our academic readership in the field international business. 


\section{A New Breed of Journals}

$A I B$ Insights has therefore contributed to creating and shaping a new and, in my opinion, invaluable new breed of IB journals, and a new space in the universe of IB publications which has recently seen "new entrants" such as AOM Insights, "an online magazine that transforms $\mathrm{AOM}$ research into actionable evidence for the workplace" (https://journals.aom.org/insights/ aboutus), and which was launched by the Academy of Management in late 2018, and Rutgers Business Review, an open access online journal which publishes, since 2016 "articles that provide novel results, tools, frameworks and perspectives for business practice [as well as] articles that provide significant managerial insights based on recently published academic studies in premier academic journals" (https://www.rbusinessreview.org/ submission-guidelines). At AIB Insights, we have been following this development in a very positive way and are welcoming these new entrants, or, in the words of Oded Shenkar (2010), "copycats" (which, by no means, I mean in a condescending or supercilious way), as they illustrate the demand for, as well as increasing importance and relevance of, this new publication space that $A I B$ Insights has defined over nearly two decades.

\section{Adjusting the Pendulum}

In the last issue that I edited, Volume 18 Issue 4, Mark Casson reflected on the early days of international business as a distinct field, around the time when IB split off from the business policy discipline and so became its own discipline (about 1970), and notes that back then "IB was the most promising field, it seemed, [and it] was global, inter-disciplinary, young and ambitious - it was ideal!" (2018: 3). Yet, nearly half a century later, he feels "so worried about the current state of international business studies" because "standards have eroded ... Data sources too are suspect ... IB studies have grown in terms of quantity but the quality is highly debatable ... There is no coherent systems view that commands general support in IB research ... [and] The most worrying feature of the modern scene $\ldots$ is that there is no gold standard for IB scholarship. There are merely conventions" (Casson, 2018: 3-5). Mark Casson further disparages the standards of traditional IB journals, their lack of a rigorous, reliable and constructive review process and their misguided incentives that reward authors for using novel yet questionable statistical techniques, developing formalized yet trivial conceptual models, and strictly abiding by restrictive norms to structure their papers rather than encourage them to focus on solving real-world problems, questioning/replicating published results and pursuing impactful research that tackles relevant questions. All of this has led to the fact that "You [IB scholars] can't engage with the bigger picture because, if you do, you will be told 'it's not research, it's just an essay." (Casson, 2018: 4)

A similar notion was conveyed by Jonathan Doh, former editor of the Journal of World Business (JWB). Jonathan Doh noted in a recent $A I B$ Insights article that, when JWB celebrated its $50^{\text {th }}$ anniversary, he reflected on the evolution of IB research in the
JWB and realized that "IB scholarship, in its early days, was often focused on tackling real-world problems related to the impact of policies toward multinational enterprises, to trade and investment agreements between and among countries, to issues of environment and development, and to many other realistic issues" and suggested that "As such, I believe that returning to some of those issues and questions will help re-energize IB scholarship while also providing valuable insights that could ultimately have relevance for policy and practice." (Doh, 2017: 15) He refers to this type of research as "phenomenon-based" and makes a convincing case for why we need more of this research in our field of international business (Doh, 2015).

The question both authors ask, explicitly and implicitly, is how we can swing the pendulum of IB publications back to academically rigorous as well as practically relevant scholarship, and to the type of questions asked in the early days of IB research in order to make our field exciting, impactful and insightful again. Jean Boddewyn and I asked a similar question in our essay titled "How to Regain Legitimacy and Relevance in a New Era for International Business: If Not Us, Who?” (Boddewyn \& Rottig, 2017), which we wrote as part of a focused issue on "Making AIB and Our Field of IB More Legitimate and Relevant," and as a contribution to a featured panel held at the 2017 AIB conference in Dubai on the same topic. Several former AIB Presidents, AIB Fellows and renowned experts contributed to these initiatives, including Simon Collinson, Jonathan Doh, Mary Ann von Glinow, Robert Grosse, and Arie Lewin. Drawing on their unique experiences and accomplishments as IB scholars, educators, administrators as well as consultants to business practitioners and policymakers, each of them provided their views on how we, the IB academic community, can contribute to swinging the pendulum in IB research and publishing back in the right direction (Collinson, 2017, Doh, 2017, Grosse, 2017, Von Glinow, 2017).

\section{Raison d'être for AIB Insights}

I believe that AIB Insights is a key conduit for publishing phenomenon-based research based on which business practitioners and policymakers can make evidence-based decisions (Rousseau, 2006, 2005). I further believe that AIB Insights constitutes a critical component in making AIB and our field of IB more legitimate and relevant again by contributing to the needed adjustment of the pendulum in IB publications as a member of a new breed of IB journals.

When I talked about the nature and value of $A I B$ Insights in my editorial commentaries, on Meet-the-Editors panels at IB conferences, and in my correspondence with (potential) authors and interested readers, I typically began by noting, half-joking and half-seriously, that AIB Insights starts with an 'A' and therefore should be considered an 'A' journal. I meant this not in the sense of a traditional "four-star" academic journal, but in the sense of its "A-star" relevance, currency, and insightfulness, and the potential impact the articles published therein promise 
to make. In fact, as is stated in the journal's editorial policy, AIB Insights does not aim to become another "traditional" academic journal as it "does not seek the kind of articles that are intended for traditional journals in international business, such as the Journal of International Business Studies." Instead, $A I B$ Insights "is intended to inform, educate, and enlighten readers with state of the art information on a topic with a broad appeal to the profession. Articles sought should be grounded in research, but presented in a readable and accessible format ... free of professional jargon and technical terms, light on references, but heavy on insight from the authors' experiences and research... [that] should prompt the reader to think about international business and international business teaching/learning in new ways... [and] have an international business and cross-disciplinary orientation."

I have often described the nature of $A I B$ Insights articles as "Written TED Talks" - fresh, topical, concise, interesting, and thought-provoking essays that present novel, innovative, and path-breaking research, knowledge, and ideas in a way that is readily accessible to a broader audience, not merely a traditional academic readership. In so doing, AIB Insights is uniquely positioned to span traditional boundaries by way of communicating new IB research findings, ideas and insights to IB scholars, educators, practitioners, policymakers as well as colleagues in other fields to inform, enlighten and disseminate "ideas worth sharing" in international business.

When asked about the raison d'être for AIB Insights, I would typically point my questioner toward the three pillars depicted in Figure 1. I believe these capture the essence of AIB Insights, illustrating what sets its apart in a field filled with traditional journals and new journal formats. In the following section, I will delineate these three pillars and, in so doing, briefly discuss the key initiatives and activities that I have spearheaded over my tenure in an editorial role for the journal.

\section{Three Pillars, Key Initiatives and Accomplishments}

\section{PILLAR 1 - Coherent \& Focused}

As is shown in figure 1, the first pillar refers to the coherent and focused nature of AIB Insights. Traditional academic journals typically publish a diverse set of longer articles on various topics in a given issue (except perhaps for special issues). This has led to the common practice of IB scholars to not read entire journal issues, but rather use electronic databases to search for articles in their specific research realms based on keywords. $A I B$ Insights articles and issues are different. First, articles are short (around 2,500 words), concise, written in an accessible format, free of professional jargon, light on references but heavy on the insight from the authors' experiences and research. We explicitly ask our authors to highlight the insight of their article in the first paragraph. In addition, for articles that are part of our Interactive Lead Article Series that we started in 2016, and our AIB Dissertation Award Focused Issue Series that we started in 2013, we ask authors to capture the insight of their articles in one "Big Question." In so doing, each article is focused on a specific insight or contribution, which is readily identifiable by the reader and presented in an easy-to-digest format. Second, $A I B$ Insights issues are focused on specific topics and so can be (and typically are) read in its entirety by our readership. Even the occasional "eclectic issue," of which we publish, on average, one per year, can be read in its entirety given that the 4-5 unrelated articles published in these issues combined have about the size (word count) of a typical traditional academic article. Third, our focused issues have specific thematic and regional emphases that are of interest and relevance across specific research realms with an international focus, and so are appealing to a wide and broad readership within and beyond our discipline of IB.

\section{Key Initiatives and Accomplishments Related to the First Pillar}

(Further) Institutionalization and Positioning of Journal Shortly after I joined the editorial team, in 2013, we implemented an apparently trivial yet crucial change: creating an $A I B$ Insights e-mail account for all external communication and switching from e-mail submissions of papers to an online manuscript submission system to facilitate a smoother, more professional and streamlined article submission and editorial review process. We further created a new cover and overall new journal design and logo for AIB Insights (starting with the first issue in 2017) in order to make its look and appearance more consistent with AIB's two other journals, the flagship research journal JIBS and the new Journal of International Business Policy (JIBP). These efforts legitimized AIB Insights as well as the "blue ocean" it occupied in the IB community, and so allowed us to more clearly position the publication as a journal. We further explic- 
itly positioned AIB Insights as a complementary journal to JIBS and JIBP with a different mission: a high-quality outlet for innovative ideas, phenomenon-based research, and thought-provoking articles in IB. In so doing, we separated $A I B$ Insights from its (widely perceived) affiliation with the AIB Newsletter (which had arisen due to the fact that in its first year of existence, in 2001, AIB Insights was published as a newsletter, and the fact that the print version of $A I B$ Insights is being mailed in the same envelop as the AIB Newsletter to capture cost synergies). These initiatives facilitated our efforts to establish $A I B$ Insights as a legitimate stand-alone journal in IB.

Increased Quality and Potential Impact of Submissions These initiatives also led to a higher quantity and better quality of paper submissions. We further increased the quality of submissions and published articles by creating a more rigorous editorial review process, and by more pro-actively working with the authors to revise their papers through a developmental process. We also reached out to seminal IB scholars and AIB Fellows to solicit high-quality and novel contributions with a high potential for impact focused on current topics and issues in IB in an attempt to increase the caliber of the journal. These authors included AIB Fellows such as Jean Boddewyn, Peter Buckley, Mark Casson, John Child, Farok Contractor, Alvaro Cuervo-Cazurra, John Daniels, Andrew Delios, Jonathan Doh, Yves Doz, Pankaj Ghemawat, Mary Ann von Glinow, Robert Grosse, Geert Hofstede, Tatiana Kostova, Yadong Luo, Klaus Meyer, Ram Mudambi, Kendall Roth, Alan Rugman, Jaeyong Song, José de la Torre, among other highly respected scholars.

Focused Issues with Thematic Emphasis In addition, we developed focused issues on relevant, current and crucial issues in the field of IB and the AIB community, and we integrated some of these issues with the annual AIB conferences. For example, Jean Boddewyn and I co-edited the already mentioned focused issue on "Making AIB and Our Field of IB More Legitimate and Relevant" (Vol. 17, Issue 2), which we published right before the 2017 annual AIB conference in Dubai. At the Dubai conference, we co-chaired a featured panel on the same topic, which included all authors who contributed papers to this focused issue as panelists (a recording of this featured panel can be accessed via the following link (AIB member login required): https://aib.msu.edu/events/2017/Videos/ShowSessionVideo. asp?videoid $=1088$.

Another example is a focused issue on "International Trade and Investment Agreements: Sovereignty at Bay in the 21st Century?" (Vol. 16, Issue 1), which Klaus Meyer and I co-edited (Meyer \& Rottig, 2016), and which is the result of discussions and presentations at the 2015 annual AIB conference in Bengaluru, India. We positioned this issue as a pedagogical tool that IB educators can use in the classroom as a basis for discussions on trade and investment agreements, with focus on the investor-state dispute settlement (ISDS) mechanism. The publication of this focused issue in early 2016 could not have been timelier, given the subsequent political situation in the United States and around the world regarding these agreements, and the related issues and controversies.

We also developed focused issues based on academic conferences outside of AIB's annual conferences and published them shortly after the respective conferences in order to disseminate novel knowledge and ideas in a timely fashion. For example, we published a focused issue based on key findings, discussions and presentations at the inaugural Global Strategy and Emerging Markets (GSEM) conference, held in Miami in 2016 (Vol. 16, Issue 4). The conference will already hold its fourth annual conference this year and is co-sponsored by the University of Miami, Northeastern University, Cornell University, and the University of Texas at Dallas.

Focused Issues with Regional Emphasis Moreover, we started an outreach program to AIB's 18 worldwide chapters to invite focused issues on novel, location-specific knowledge and ideas from their respective regions. The editorial team of $A I B$ Insights represented the journal at several AIB chapter conferences by participating in "Meet the Editors" panels and professional development sessions, and we worked with the leaderships of these chapters to invite and develop contributions from these regions. Based on these efforts, we have published focused issues with regional emphasis, comprising the Middle East North Africa (MENA) region (Vol. 13, Issue 2), guest-edited by Melodena Stephens Balakrishnan (then-President of the AIB MENA Chapter), the Central and Eastern European (CEE) region (Vol. 18, Issue 1), co-guest-edited by Łukasz Puślecki (Chair of AIB's CEE Chapter), Piotr Trączyński (Vice Chair for Communication at AIB's CEE Chapter) and Mirosław Jarosiński (2015 Program Chair for AIB's CEE Chapter), and the Sub-Saharan Africa (SSA) region (Vol. 18, Issue 4), co-guest-edited by Ifedapo Adeleye (Chair of the 2018 AIB SSA conference), and Nathaniel Boso (Professor in International Marketing and Entrepreneurship and Dean of the School of Business at Kwame Nkrumah University of Science and Technology, Ghana). A focused issue on the Latin American region, in collaboration with the leadership of the AIB Latin America (AIB-LAT) chapter, is currently being finalized and will be published in an upcoming issue.

Invited, Guest-Edited Focused Issues Furthermore, in addition to coordinating the aforementioned focused issues with regional emphasis with the respective AIB chapter leaderships and guest editors from these regions, we have reached out to highly respected and accomplished scholars to guest-edit focused issues in their respective realms of expertise in order to invite a diverse set of novel perspectives. For example, we published a focused issue on the "Leadership Effectiveness in Africa and the African Diaspora (LEAD)" project (Vol. 17, Issue 1), which was guest-edited by Betty Jane Punnett (the founding editor of AIB Insights and an expert on emerging market research). We also published a focused issue on "Stepping on Cultural and 
Religious Assumptions" (Vol. 14, Issue 2) based on the "Stepping on Jesus" controversy that had happened at FAU, which was guest-edited by Mark Peterson (Professor of Cross-Cultural Management at FAU at the time, and currently Professor and Hofstede Chair in Cultural Diversity at Maastricht University). Forthcoming guest-edited focused issues include topics such as "Gender Issues and Research in IB," which has been guest-edited by Amanda Bullough (former President of AIB's Women in the Academy of International Business - WAIB) as well as "Studying Modern Slavery and the Role of IB Scholarship," which is being guest-edited by Snejina Michailova and Christina Stringer from the University of New Zealand.

\section{PILLAR 2 - Relevant \& Timely}

The second pillar (see Figure 1) refers to the relevance and timeliness of $A I B$ Insights. First, whereas it may take several years for research to be published in (top-ranked) traditional academic journals due to the considerable amount of time for the review, revision and publication process, AIB Insights has a clear focus on a quick turnaround of submissions, and a timely publication of accepted articles. Second, the discussion regarding 'relevance and implications of research findings for IB business practice and policy' is often merely an afterthought during the publication process at traditional academic journals, and authors reluctantly acquiesce to add such a discussion only because they are required to do so in order to clear a "conditional acceptance" decision after a lengthy revision and resubmission process. At $A I B$ Insights, however, the phenomenon-based nature of an article and the clear explication of its insight, relevance and implications are key criteria for being accepted for publication, and so are central to the work that is being published in the journal. Third, as opposed to the lengthy review and publication process that makes it a challenge for traditional academic journals to quickly respond to current developments in international business, $A I B$ Insights is able to frequently publish articles on current trends and developments in a very timely way.

\section{Key Initiatives and Accomplishments Related to the Second Pillar}

AIB Dissertation Award Focused Issue Series One initiative that illustrates how we accomplish the relevance and timeliness of AIB Insights publications is the annual AIB Dissertation Award Focused Issue Series, which we launched in 2013 - during my first year of editorial service for AIB Insights. Typically, it takes several years before dissertation research is published in traditional academic journals (as a previous AIB Dissertation Award recipient, I am speaking from experience here), and it takes even more time until the contributions of a dissertation are recognized in the field. In order to draw timely attention to the innovative, novel and potentially impactful dissertation research that has been selected for the final round of the annual AIB dissertation award competition, AIB Insights publishes extended abstracts (about 2,500 words) of the award-winning and award-nominated dissertations in the field of international business in the journal issue directly following the respective annual AIB conference. In so doing, AIB Insights enables and encourages a fresh and fruitful conversation on the respective dissertation topics. As a result of this initiative, our dissertation award series, which we have published annually over the past six years (see the third issue of each annual volume) has become an invaluable conduit for the timely dissemination of the latest, state-of-the-art dissertation research in international business.

Eclectic Issues to Capture Current Topics and Developments in IB Another illustration of how we facilitate relevant and timely AIB Insights publications are our eclectic issues with articles on current topics in IB research, pedagogy and business practice, which we publish about once a year. Examples include an article by Pankaj Ghemawat (2016) titled "Beyond Brexit: An Initial Analysis and Questions for the AIB Community" that we published shortly after the Brexit vote in the United Kingdom in the summer of 2016. Other examples include articles by Farok Contractor (2016) titled "Tax Avoidance by Multinational Companies: Methods, Policies, and Ethics," by James Nebus (2016) titled "Irish-Dutch Sandwiches, Corporate Inversions, and Arm's Length Transactions: International Tax for IB Courses," and by Robert Mefford (2017) titled "Turbulence in the Currency Markets - What Does It Mean for International Business?". These articles tackle very timely and relevant issues, and so inform IB scholars, business practitioners, policymakers, and educators, who can readily use these articles in the classroom.

\section{PILLAR 3 - Interactive \& Accessible}

The third pillar (see Figure 1) refers to the interactive and accessible nature of $A I B$ Insights. First, most traditional academic journals are exclusively accessible through universities and other research-oriented institutions which are required to subscribe to expensive databases that provide access to published academic research. In fact, the current system has (somehow) convinced academic scholars to sign over the copyrights to their intellectual property, and so provide the results of their research "free of charge," to for-profit publishing companies which, in turn, charge the very universities and research institutions that pay these scholars to do research in the first place for access to their journals that publish this research. AIB Insights, however, is published by the Academy of International Business and authors retain the copyrights for their work. Every $A I B$ Insights issue is mailed, in print format, to AIB's more than 3,000 members in over 90 countries as well as made available to any interested reader (whether a registered AIB member or not) in digital format through AIB Insights' open-access website at https://aib.msu.edu/publications/insights. This website also features an archive of all previous AIB Insights issues. Second, traditional academic journals do not allow readers to comment on published articles or respond to the authors of these articles directly. AIB Insights does so, however, through its interactive commenting feature which is available on the aforementioned website. Third, traditional academic journals are typically accessible through databases and print subscriptions only, 
whereas AIB Insights content is also disseminated through prevailing social media platforms.

\section{Key Initiatives and Accomplishments Related to the Third Pillar}

Interactive Lead Article Series In 2016, during my first year as Editor, we launched an innovative series of lead articles by renowned IB scholars and thought-leaders that raise insightful and thought-provoking questions in an attempt to engage the AIB community in fruitful conversations that we hope will advance our field (Vol. 16, Issue 2). This series involved authors such as Jean Boddewyn (2016) who asked, "Is Your 'IB' Research Truly 'International'?” and Andrew Delios (2017), who built on Jean Boddewyn's article and posed the follow-up question of "Are You a 'Truly International' Scholar?" This series also included articles by John Child (2018), who asked, "Should Your IB Research Deal with Power?" and Mark Casson (2018), who queried, "Should We Be Concerned about IB Research?" We encouraged our readers to actively think about these fundamental questions and respond to these authors directly. To facilitate this effort, we added an interactive "Comments" feature onto the AIB Insights website, which allows our authors and readers to correspond about these important questions, and provides an opportunity for any interested reader to follow the respective conversations. We also post the most insightful comments and dialogues on the AIB Insights website and, selectively, publish these interactive dialogues in subsequent AIB Insights issues (see, e.g., Boddewyn, 2016).

Communications Director and New Social Media Initiative When the idea of $A I B$ Insights was conceived in the very late 1990 ies, the publication reflected a different, largely pre-internet and pre-social media world. Two decades later, technological globalization has changed our field and the way we communicate, and new social media tools that "applicationized" communication have permeated virtually any realm in academia and business practice. In order to further expand and enhance our external journal communication with our readership and (potential) authors, we added a new communications director position to our editorial team, and launched an initiative to improve $A I B$ Insights' online platform and social media presence. This initiative is also aimed at developing a new $A I B$ Insights social media application. This new application, which we envision to be compatible across various devices (from smart phones, tablets to more traditional laptops and desktop computers), would allow for a more contemporary and interactive publication of journal content, create a real-time and more convenient way for our authors and readers to correspond and engage in two-way dialogues, and integrate as well as leverage new social media tools to more effectively and efficiently disseminate knowledge and ideas.

\section{A Final Look Back and Moving Ahead}

In closing this farewell editorial, I would like to take this opportunity to thank all my great colleagues and friends of $A I B$ Insights for their dedicated support of the journal. First, I would like to thank Tunga Kiyak, AIB Managing Director, whose support of $A I B$ Insights has been exceptional. In a nutshell, Tunga rocks! A special thanks to Anne Hoekman, AIB Insights Managing Editor, who greatly supported and facilitated my work in an editorial role for the journal.

All previous editors of the journal deserve great thanks for their vision and devoted work, including the Founding Editor, Betty Jane Punnett, who served from 2001-03 and who has continued her support for the journal over the years and recently guest-edited a focused issue (Volume 17, Issue 1); Tamir Agmon, who served as the second Editor from 2004-08 and particularly contributed with his cross-disciplinary focus; Ilan Alon, who served as Editor from 2009-12 and whose vision and innovative thinking have set $A I B$ Insights on a new path and growth trajectory; and Romie Littrell, who served as the journal's fourth Editor from 2013-15 and with whom I have had the pleasure of working during my tenure as Associate Editor. In order to highlight and honor the great work of previous editors, we published a special feature in my first issue as (the fifth) Editor of AIB Insights (Volume 16, Issue 1).

Many thanks to John Mezias, with whom I always enjoy working, and who has served as Associate Editor during my 3-year term as Editor. John has assumed the role of Editor for the current, 3-year term, and I am thankful to the AIB Executive Board and the selection committee for electing John as well as Bill Newburry (who will serve as the new Associate Editor) as the new editorial team. Thanks also to Chei Hwee Chua, who we brought onto our team as Communications Director last year, for bringing her social media expertise and excitement for this position to $A I B$ Insights.

A special thanks to Jean Boddewyn, who has not only supported the journal over its entire existence by authoring numerous articles (starting with an essay he published in the second volume of the journal in 2002), but who has also been instrumental in facilitating the launch and development of a number of projects an initiatives.

Finally, I would like to thank all of our dedicated authors, guest editors, and interested readers as well as the Academy of International Business, its secretariat and executive board for the confidence and trust they have bestowed in me, and for their support of our editorial initiatives.

In my inaugural editorial commentary as Editor, I mentioned that "There has been no other time more exciting for international business. International challenges and opportunities are permeating business activities in nearly every country and industry around the 
globe, economic boundaries across nations have nearly disappeared, technological innovations and instantaneous global communication are transforming the way people and firms around the world conduct business, and the way universities around the globe educate. Institutions in form of political, legal, economic and socio-cultural rules of the game are becoming increasingly complex in both developed and emerging markets, and thus more fascinating to study. With the beginning of the second half of these post-recession "Transformative Teens" in this 21st century comes the exciting opportunity to explore new knowledge, fresh ideas and the next frontiers in international business. AIB Insights constitutes a distinct outlet for such new, innovative and path-breaking knowledge and ideas" (Rottig, 2016). Three years later, I still believe that these statements and observations are current, relevant and timely, and I am convinced that the format, quality and impact of AIB Insights will remain to be relevant for many years and decades to come.

Under the leadership of Lorraine Eden, who has served as President from 2017-18 and currently serves as Immediate Past President, the AIB has developed a comprehensive publications strategy and a standing publications committee, which comprises as members, among others, the Editors of AIB's three journals: JIBS, JIBP, and AIB Insights. Based on this new publication strategy initiative, my discussions with the leadership of AIB and fellow journal editors during the AIB publications committee and related meetings, as well as based on my experiences as an editor, I believe that the Academy of International Business, and our field of international business, is interested and motivated to nurture a new breed of journals of the caliber of AIB Insights. I further believe that the AIB and our field of IB are willing to fuel the "blue ocean shift" that has sparked a movement toward swinging the pendulum in IB research and publications back in the right direction.

When taking a final look back, I am very proud of what we have accomplished during my editorial leadership of AIB Insights over the past six years, and I am thrilled about the upward trajectory we have put our journal on. In moving ahead, I could not be more confident in John Mezias and Bill Newburry, who will serve as the new editorial team over the 2019-21 term, and in their ability to take AIB Insights to the next level.

Go AIB, Go Insights!

\section{References}

Boddewyn, J. J. 2016. Featured Commentary: What You, Readers of AIB Insights, Said: Responses to the Article "Is Your 'IB' Research Truly 'International'?" AIB Insights, 16(2): 18-19.

Boddewyn, J. J. 2016. Is Your "IB" Research Truly "International"? AIB Insights, 16(2): 3-5.

Boddewyn, J. J., \& Rottig, D. 2017. How to regain legitimacy and relevance in a new era for international business: If not us, who? AlB Insights, 17(2): 3-6.
Casson, M. 2018. Should we be concerned about IB research? AIB Insights, 18(4): 3-5.

Child, J. 2018. Should Your IB Research Deal with Power? AIB Insights, 18(2): 3-6.

Collinson, S. 2017. The declining relevance and legitimacy of IB scholarship in a world that really needs it. AIB Insights, 17(2): 7-10.

Contractor, F. J. 2016. Tax avoidance by multinational companies: Methods, policies, and ethics. AIB Insights, 16(2): 10-13.

Delios, A. 2017. Are You a "Truly International" Scholar? AIB Insights, 17(4): 3-5.

Doh, J. P. 2015. From the Editor: Why we need phenomenon-based research in international business. Journal of World Business, 50(4): 609-11.

Doh, J. P. 2017. Phenomenon-based research in international business: Making IB relevant again. AIB Insights, 17(2): 14-16.

Ghemawat, P. 2016. Beyond Brexit: An initial analysis and questions for the AIB community. AlB Insights, 16(3): 3-6.

Grosse, R. 2017. Global value chains, emerging markets, and IB education. AlB Insights, 17(2): 17-19.

Kim, W. C., \& Mauborgne, R. 2017. Blue ocean shift: Beyond competing - proven steps to inspire confidence and seize new growth Boston, MA: Harvard Business Review Press.

Kim, W. C., \& Mauborgne, R. 2015. Blue ocean strategy: How to create uncontested market space and make the competition irrelevant. Boston, MA: Harvard Business Review Press.

Mefford, R. N. 2017. Turbulence in the currency markets -- What does it mean for international business? AIB Insights, 17(4): 18-22.

Meyer, K. E., \& Rottig, D. 2016. International trade and investment agreements: Sovereignty at bay in the 21 st century? AIB Insights, 16(1): 3-6.

Nebus, J. 2016. Irish-Dutch Sandwiches, corporate inversions, and arm's length transactions: International tax for IB courses. AIB Insights, 16(2): 14-18.

Rottig, D. 2016. Editorial Commentary. AlB Insights, 16(1): 2.

Rousseau, D. M. 2006. Is there such a thing as "Evidence-Based Management"? Academy of Management Review, 31 (2): 256-69.

Rousseau, D. M. 2005. Is there such a thing as Evidence-Based Management? Address: Speech presented to the Academy of Management, Honolulu, HI.

Shenkar, O. 2010. Copycats: How smart companies use imitation to gain a strategic edge. Boston, MA: Harvard Business Review Press.

Von Glinow, M. A. 2017. Plus ça change, plus c'est la même chose? Or, that was then, this is now! AlB Insights, 17(2): 11-13.

Daniel Rottig (drottig@fgcu.edu) is Associate Professor of International Business and Strategic Management in the Lutgert College of Business at Florida Gulf Coast University. His research has won several awards and award nominations from the Academy of International Business and the Academy of Management as well as reputable journals and publishers. He is a passionate educator who has taught in graduate and Executive programs at leading universities in Australia, Asia, Latin America and the United States. 